\title{
ARTE E CONHECIMENTO EM ARISTÓTELES
}

\author{
PAULO BUTTI DE LIMA \\ Universidade de Bari (Itália)
}

\begin{abstract}
Resumo: O exemplo do Édipo Rei de Sófocles pode nos introduzir em um tema central da reflexão aristotélica na Poética e em outros tratados do filósofo: a relação entre arte e conhecimento. Este artigo procura investigar alguns tópicos deste tema, considerando em particular a discussão sobre as causas da poesia no quarto capítulo da Poética, e a função das imagens no processo de conhecimento e imaginação. A relação entre mímesis e a interioridade da alma aparece na análise aristotélica do intelecto e, no que diz respeito às artes, no campo da música.
\end{abstract}

Palavras-chave: Aristóteles, téchne, epistéme, poética, imagem, tragédia.

1. Segundo Aristóteles, o gênero trágico alcança a sua perfeição, e, portanto, a sua natureza, com Sófocles. Entre as obras trágicas, Aristóteles admira, de modo particular, o Édipo Rei. Dois elementos chamam sua atenção nesta obra: a construção da trama segundo uma relação de verdade e o processo de conhecimento que caracteriza o percurso do herói. Este processo é fonte de dor, para Édipo e para nós, ouvintes. Todavia, para quem deseja conhecer, a dor do conhecimento, representada pelo poeta, pode causar perplexidade.

O Édipo Rei apresenta, em sua forma superior, o que é peculiar a toda obra poética, trágica ou épica. Constata Aristóteles que na obra de Sófocles o que não é verossímil não participa propriamente da trama. É por meio do verossímil que se dá o reconhecimento de Édipo - ou seja, o modo em que o personagem toma consciência da própria situação. Este reconhecimento está na origem da inversão no destino do herói. A coincidência entre reconhecimento e peripécia, aspectos essenciais de toda narração poética, revela a grandeza de Sófocles. Mas o conhecimento da verdade é causa de sofrimento: para o personagem e para o ouvinte, que, sem precisar dos vários mecanismos da cena, treme e sente piedade ${ }^{1}$.

1 Aristóteles, Poética, 4, 1449a15 s. (Ésquilo e Sófocles são citados após a referência à tragédia que atinge sua natureza e cessa de se transformar: podemos deduzir que a inovação realizada 
Tremor e piedade: estas eram as palavras escolhidas por Górgias para indicar o poder ambivalente da expressão poética. A poesia "suscita nos ouvintes um tremor de medo, uma piedade que faz chorar, um desejo de se comover". Para Górgias, trata-se da capacidade de criar ilusão, de causar prazer e dor, que é possuída pelo poeta, mas também pelo prosador. Górgias fala do poder de um logos que guia as almas e que, em sua natureza de phármakon, envenena e encanta ${ }^{2}$.

As emoções de Górgias são o resultado de um engano e este engano seria inerente à criação poética. Visto no Édipo, o engano poético se esconde sob o apelo contínuo à verdade na construção da trama. O ouvinte do Édipo é consciente do que o herói ainda não sabe, durante o processo de reconhecimento: sabe o que o herói deve descobrir. Deste modo, a dor do conhecimento de Édipo se transpõe na dor do ouvinte. $\mathrm{O}$ efeito trágico tem origem na transformação desta dor do conhecimento em prazer.

Conhecimento e engano, prazer e dor são termos que se apresentam segundo diferentes relações de analogia, já no interior da situação trágica. Os homens não se importam com a verdade de seus sonhos, procura-se em vão indagar sobre todas as coisas: o aviso de Jocasta, necessariamente desatendido, ilumina a conseqüência da investigação de Édipo ${ }^{3}$. Diante da dor de Édipo, e da nossa dor, inseparável da consciência alcançada pelo herói, o prazer pela obra se explica duplamente, do ponto de vista do conhecimento: com a constatação do engano poético - sentimos prazer porque sabemos que o que é representado não "acontece" do mesmo modo conosco - ou, ao contrário, no reconhecimento de uma relação de verdade - sentimos prazer porque constatamos que a narração é verossímil. Segundo esta última hipótese, o prazer não teria origem na ilusão poética, mas em seu oposto, invertendo a experiência dolorosa do conhecimento do herói trágico.

A "purificação" da alma por meio da tragédia representa, talvez, uma resposta às dificuldades que assim se colocam, mas não supera a alternativa que é

por Sófocles, último mencionado, tenha levado o gênero à sua perfeição); 11, 1452a22 s. (Édipo Rei, reconhecimento e peripécia); 14, 1453b6-7 (tremor e piedade, phríttein kaì eleên); 15, 1454b6-7 (exclusão do que é "ilógico" na cena); 16, $1455 \mathrm{a} 18$ (reconhecimento e verossimilhança). Para a "purificação", kátharsis, referida ao "temor e piedade", éleos kaì phóbos, ver Poética, 6, 1449b28 (e Política, VIII, 1341b32-1342a22). Outra referência ao Édipo: o caráter superior do personagem e a harmatía trágica em Poética, 13, 1453a11 s.

2 Górgias, Elogio de Helena, D-K 82 F 11,9: phríke períphobos kaì éleos polydakrys kaì póthos philopenthés.

3 Édipo Rei, vv. 977-983; 1068. 
deste modo apresentada. Mesmo considerando a teoria da kátharsis o ponto culminante da reflexão aristotélica sobre a tragédia, ela não oferece uma explicação, em sua brevidade, ao problema do conhecimento ou da ilusão trágica. Com efeito, as considerações aristotélicas sobre a dor e o prazer trágicos são o resultado de reflexões sobre paradoxos que entrelaçam, de forma inextrincável, conhecimento filosófico e experiência poética ou artística. Por um lado, a representação do conhecimento e de seus processos; por outro, a observação de toda forma de arte (téchne) que conduz a uma representação (mímesis). Entre conhecimento e ilusão, entre arte e ciência, fica a perplexidade: por que sentimos dor por Édipo, em sua descoberta da verdade?

Mais do que uma vez os filósofos antigos observaram o conhecimento e a arte a partir da relação de prazer e dor. Podemos lembrar alguns exemplos. Para Anaxágoras, ver e escutar são sensações dolorosas, e se não o percebemos é porque estamos habituados. Não devemos esquecer a dor que provoca em nós algumas sensações mais nobres, segundo Platão, como a visão da luz, para o homem liberado de sua prisão na caverna. Também Aristóteles, que não hesita em falar do prazer relacionado a cada sensação, e a todo processo de conhecimento, lembra a existência de sensações dolorosas, como a visão de cadáveres, e afirma que o conhecimento se adquire com dor ${ }^{4}$.

No que diz respeito à arte, Platão coloca a tragédia entre os prazeres mistos da alma - quando o prazer se mistura à dor -, aos quais correspondem os prazeres mistos do corpo, como coçar. Já Aristóteles constata que os prazeres provocados pela visão, como o prazer pelas cores, formas e desenho, são prazeres corporais, e o mesmo pode ser dito do prazer pela audição, como recitar e cantar. Entre os prazeres da alma encontramos o amor por aprender e conhecer - a filosofia seria sua expressão - e o prazer pelas honras - o que deve ser interpretado como o campo da política. Mas ao filósofo e ao político, cujo prazer provém da alma e não do corpo, Aristóteles acrescenta um terceiro personagem, o amante de contos e narrador (o phylómythos kaì diegetikós), que podemos interpretar, de forma ativa e passiva, como aquele que vive no mundo das narrações. Não sabemos entre quais desses

4 Anaxágoras, D-K 59A94 (de Aristóteles, Ética a Nicômaco, III, 1154b7). Platão, República, VII, 515e-516b (onde se fala do algên, da dor provocada pela visão da luz). Aristóteles, Ética a Nicômaco, X, 1174b20 (sensação e prazer: katà pâsan gàr aísthesín estin hedoné); Poética, 4, 1448b10 (imagem do que é doloroso). Dor na aprendizagem: Política, VIII, 1339a27 s. (metà lypes gàr he máthesis). 
extremos, entre o prazer corporal pela audição e o prazer espiritual pelo narrar, deveríamos incluir o prazer poético, ou, mais em particular, o prazer trágico 5 .

Prazer e dor marcam as relações de percepção, representação ou conhecimento entre o homem e a natureza. Prazer e conhecimento são inerentes não somente à relação que se instaura entre o criador (poietés) e a natureza (physis), mas também entre a obra poética e seu ouvinte. Aristóteles observa os processos de criação e fruição das obras imitativas e avalia estes processos a partir da excelência da obra em cada aspecto e a partir da função de conhecimento: segundo a verdade na composição - a verossimilhança está na essência da narração poética - e segundo a passagem da dor ao prazer, na fruição.

Se o filósofo, ou o investigador da natureza, observa o mundo e suas aporias levado pela maravilha inicial, o autor de uma poética observa a arte enquanto conduz a um determinado "criar" (poieîn), à composição de obras que possuem com o mundo uma correspondência precisa: uma relação de mímesis, imitação ou representação. São modos diferentes que o homem possui de se colocar diante da natureza. Se a arte imita a natureza, e às vezes a completa, quando a natureza é incapaz de perfeição, conhecer é voltar à natureza, é alcançar o que pertence à natureza do homem. Aristóteles observa a relação entre arte (téchne) e natureza (physis) e a considera sob a forma de observação ou conhecimento: ou seja, sob a forma da theoría 6 .

2. São duas as causas que deram origem à poesia e ambas pertencem à natureza do homem 7 . Do mesmo modo em que o investigador da natureza observa as causas dos fenômenos naturais, o autor da Poética analisa a origem das formas poéticas.

5 Platão, Filebo, 48 a s. (prazer e tragédia). Aristóteles, Ética a Nicômaco, III, $1117 \mathrm{~b} 28$ s. (prazeres da alma e do corpo: o argumento é a sophrosyne). Quanto à política, pode-se lembrar que o legislador (homem "político" em senso próprio, segundo Aristóteles) é também um "pintor" de politêaai, para Platão: República, VI, 501 a s.; 501c; Leis, VI, 769a-770b: ao prazer pelas honras, para o homem de ação, se deve acrescentar o prazer da representação, para quem oferece normas para a vida em comunidade.

6 Aristóteles, Física, II, 199a15-16: a arte imita mas também completa, epitelê̂, a natureza (o exemplo para este "completar" é arquitetônico, o que coloca a arquitetura numa posição singular entre as artes); cf. Protrético, 13; Retórica, I, 1371a32 s. (conhecimento e natureza).

7 Aristóteles, Poética, 4, 1448b3-24. 
Aristóteles nos revela, brevemente, o mundo que precede a poesia: no que diz respeito a cada indivíduo, o mundo da infância; no que diz respeito aos homens em geral, um mundo indefinido, pré-homérico, quando somente se improvisava o que mais tarde se tornará obra poética. Seguindo Aristóteles, em suas breves considerações no início do quarto capítulo da Poética, estamos para reconduzir a arte, que "imita a natureza", ao campo da natureza. Não, paradoxalmente, porque arte e natureza sejam o mesmo, mas porque a arte deve ter origem em uma disposição natural. Enraizada na natureza, a arte se dirige a esta sob a forma de mímesis .

A primeira causa da poesia consiste no fato que os homens imitam naturalmente. Também outros animais o fazem, mas os homens são mais propensos a uma tal atividade. Não se trata somente de intensidade: através da imitação - entendamos, praticada pelos homens na infância - há origem os primeiros conhecimentos ${ }^{8}$. Por transposição, podemos imaginar que poesia e filosofia nascem da imitação, praticada na infância da humanidade. Persistir na mímesis tornará o homem poeta, pintor, escultor, músico, bailarino. Superá-la, filósofo.

A imitação é o critério com o qual, logo no início da Poética, se analisa o conjunto das obras poéticas existentes. Aristóteles observa estas obras, e, ao mesmo tempo, o que se diz sobre elas. O filósofo considera criticamente a visão comum dos homens, que relacionam a poesia ao compor versos (ou, mais propriamente, "em métrica"). A particularidade da poesia - expressa também nos nomes dos gêneros - corresponderia, segundo a compreensão habitual, ao uso de uma linguagem medida, marcada por um ritmo preciso, distinta, pois, da fala comum, quotidiana. Ao contrário, Aristóteles considera que não a métrica, não a particularidade rítmica ou melódica da linguagem, mas a mímesis conota o ato poético. Com uma primeira conseqüência importante, normativa em relação à própria tradição que observa: se alguém utiliza a "métrica" (ou seja, versos) para uma composição não poética, não é poeta. Nem todas as obras que os homens estão habituados a ver como obras poéticas o são de fato.

8 Poética, 4, 1448b3 s.: "Duas causas em geral parecem ter dado origem à poesia, ambas por natureza. Imitar é natural aos homens desde a infância e nisto se distinguem dos demais animais, porque imitam mais e adquirem os primeiros conhecimentos através das imitações..." Sugeriu-se, para esta imitação infantil, os jogos teatrais das crianças. Entre o imitar "algo" em vista de uma representação (teatral, pictórica, poética), e imitar "alguém" para obter a habilidade na imitação, há origem duas visões da mímesis que terão importantes e distintas tradições. Exemplo da primeira forma de imitação: a imitação com imagens de animais ou cadáveres (4, 1448 b 9-12, infra). Exemplo da segunda forma: os poetas devem imitar os bons pintores $(15,1454 \mathrm{~b} 9)$. 
Por meio da mímesis definem-se os campos distintos da poesia e da filosofia - mesmo se Aristóteles não recorre, em um tal contexto, ao termo que distingue sua atividade e que ele realizava em prosa. Na consideração tradicional de quem fosse filósofo, ou sábio, podiam ser incluídos vários "poetas", ou compositores em linguagem métrica. Ao contrário, diz Aristóteles, um autor como Empédocles, que utiliza a mesma métrica de Homero, não é poeta, mas physiológos: constrói discursos sobre a natureza. Homero, como poeta, pratica a mímesis, imita a natureza. Empédocles não a imita, mas (acrescentemos o que não se diz aqui no texto), a explica, observa suas causas. Por qual motivo deveriam os poetas exprimir-se em linguagem métrica? ${ }^{9}$

Esta separação entre imitação, por um lado, e conhecimento da natureza, por outro, não impede uma aproximação originária. A mímesis é também conhecimento, mesmo se limitado. A mímesis é o primeiro conhecimento dos homens, é o conhecimento dos homens em sua infância. Por conseguinte, não somente a poesia, mas também a filosofia deve ter sua origem na mímesis. Aprender e maravilharse, na origem do comportamento filosófico, são agradáveis. Observa Aristóteles, na Retórica, que também o que é semelhante a estas atividades ou sensações provoca prazer, como a obra que é o resultado de uma imitação (tò mimetikón). São agradáveis "a pintura, a escultura e a poesia e todas as coisas bem imitadas, mesmo se o objeto imitado não é agradável”. A este mundo da filosofia e da arte se adicionam, como fonte de prazer, a peripécia e salvar-se dos perigos: uma exemplificação épica, "odisséica", do mundo imitativo evocado. Mas se aprendemos agradavelmente, de forma limitada, através da imitação da natureza, e oferecemos assim razão de um nosso comportamento e de nossa arte, poderíamos dizer o mesmo se a natureza que é imitada nos pertencesse em sua forma mais íntima? Como veremos, também o conhecimento da alma não pode ser explicado sem as formas de imitação ${ }^{10}$.

3. Se a primeira causa da poesia conduz o princípio da produção artística à nossa natureza, a segunda causa se mostra menos clara, sendo diferentemente identificada pelos comentadores do texto aristotélico. Não sabemos se nesta o filósofo esclarece não somente a razão do ato de "criar" (poiê̂n), mas também de

9 Para a relação entre métrica e mímesis, e para a exclusão de Empédocles do campo da poesia, ver Poética, 1, 1447b16-20.

10 A relação entre conhecer e maravilhar-se é mencionada por Aristóteles no primeiro livro da Metafísica (A, 980a s.; 982b12). Na Retórica (I, 1371b4s.), a estes prazeres se adicionam os prazeres miméticos, salvar-se dos perigos e a peripécia. 
"fruir" (theoreîn) das obras, ou se, ao contrário, observa sempre o ato criativo e, além do criar que imita e conhece, individua em nós um criar não imitativo.

Para alguns, a segunda causa da poesia corresponde ao prazer que a mímesis causa em todos os homens ${ }^{11}$. Se, quando praticam a mímesis, os homens adquirem conhecimento (e, acrescentemos, sentem prazer), quando observam ou escutam as obras miméticas os homens sentem prazer (e, como veremos, adquirem conhecimento). Na primeira causa, Aristóteles considera a produção da poesia ou das obras miméticas em geral, e fala do ato infantil ou primitivo de imitar. Nesta suposta segunda causa, Aristóteles pensa na fruição das obras, não em sua composição, e acentua o prazer e o conhecimento de uma observação que não é somente infantil ou primitiva, mas é comum a todos os homens, mesmo se de forma distinta entre os filósofos e os demais. Fica implícito que conhecimento e prazer se combinam tanto ao se produzirem obras miméticas, quanto ao observá-las.

Outros leitores da Poética negaram, porém, que o prazer nas imitações corresponda à segunda causa que Aristóteles atribui à origem da poesia. $O$ prazer seria somente um aspecto da primeira causa: os homens imitam por natureza e sentem prazer quando observam as imitações. A verdadeira segunda causa da poesia seria revelada em seguida no texto: não somente a mímesis é natural aos homens, mas também o ritmo e a harmonia, e os homens que, em princípio, eram naturalmente mais dotados quanto a estes três elementos - mímesis, ritmo e harmonia -, por meio de improvisações deram origem à poesia ${ }^{12}$.

Entre estas duas supostas e discutidas "segundas causas" da poesia, Aristóteles introduz um exemplo do prazer que provém da observação das imitações. Se as sensações relativas a alguns objetos provocam em nós dor, as sensações relativas às imagens ou cópias destes objetos nos causam prazer. Haverá um prazer tão mais intenso quanto mais precisas forem estas imagens. Partindo de uma experiência comum, Aristóteles constata que a visão de animais abjetos e cadáveres é, para nós, "dolorosa" (lyperôs). Esta visão torna-se, porém, agradável quando se trata de imagens que têm por objeto estes mesmos animais e cadáveres. O filósofo procura explicar esta mudança, da repulsa em prazer, notando que através da imitação nós

11 Poética, IV, 1448b8: “...e todos terem prazer nas imitações”.

12 Poética, IV, 1448b20: "Sendo em nós por natureza o (ato de) imitar, a harmonia e o ritmo - e é claro que os versos (métra) são parte do ritmo -, os que eram mais dotados a isso por natureza, aos poucos, a partir de improvisações, deram origem à poesia". 
aprendemos. A mímesis, não somente praticada, mas também observada, é um processo de conhecimento ${ }^{13}$.

O exemplo proposto das figuras de animais e cadáveres terá uma longa e rica tradição. Trata-se, porém, de um exemplo singular. Em primeiro lugar, porque não diz respeito às palavras, mas às imagens. Esperaríamos ver uma referência ao modo em que uma poesia realiza uma imitação, e como uma poesia, que imita fatos por si mesmo dolorosos, provoca em nós prazer. Ficamos sem saber com precisão se o mesmo processo ocorre com a poesia, ou se a mímesis que a poesia realiza - mímesis de ações e modos de vida, dirá Aristóteles, não de objetos ou indivíduos - é completamente diferente da mímesis da pintura e da escultura. A pintura, meio figurativo distinto das palavras, como se nota no início do tratado, pode ser de auxílio à poesia, indicando claramente a natureza agradável do ato mimético. Elemento mais simples, talvez, e mais útil a tal fim, mas também forma extrínseca, que parece introduzida na Poética a partir de reflexões que o filósofo desenvolve em outros momentos: como veremos, trata-se de considerações sobre os processos de imaginação e sobre a diferença entre o conhecimento das causas e o conhecimento imitativo. Mas também considerações sobre a ação da natureza e sobre a atividade do que em nós é mais divino ${ }^{14}$.

4. É curioso o interesse aristotélico pelos animais "abjetos" ou "desprezíveis” (tà thería atimótata). Estes animais, cuja visão é dolorosa, mas que se oferecem prazerosamente à nossa percepção através da mímesis, são lembrados por Aristóteles em uma outra ocasião, quando procura demonstrar o prazer do conhecimento natural. No tratado Sobre as partes dos animais, procura-se justificar o estudo da zoologia: o que significa dar razão também do conhecimento de realidades ínfimas e desagradáveis do mundo animal. Podemos imaginar que entre os discípulos aris-

13 Poética, IV, 1448b9 s.: "É sinal disso o que acontece de fato: as mesmas coisas que vemos com dor, quando observamos suas imagens mais precisas sentimos prazer, como as formas dos animais mais desprezíveis e cadáveres. A causa é a seguinte: aprender não é prazeroso somente para os filósofos, mas também para os demais, mas estes participam (deste prazer) por pouco tempo. Por isso têm prazer vendo as imagens, porque observando aprendem e raciocinam sobre o que é cada coisa, por exemplo que este é aquele". Na tradição do texto da Poética em época moderna, à leitura "desprezíveis" ou "abjetos" (atimótata) se alternou a leitura "selvagens" (agriótata). A esta variação e a outras conseqüências na interpretação deste passo dedico um trabalho de próxima publicação.

14 Outros momentos, na Poética, em que encontramos uma analogia entre imagens e poesia: 2, 1448 a $5-7 ; 6,1450$ a 26; 15, 1454 b 9; 25, 1460 b 5 . 
totélicos, habituados a tratar da natureza ou do que está além da natureza, o projeto enciclopédico que fazia de cada elemento do cosmo objeto de conhecimento podia criar alguma perplexidade. Por qual motivo dedicar-se ao estudo do que não somente é inferior, no plano dos seres viventes, mas que é também desagradável às nossas sensações?

Em tudo o que é natural, diz Aristóteles, há algo maravilhoso. Em todos os seres há algo natural e belo. Aristóteles refere-se ao mundo de Heraclito, povoado por deuses. Mas não se trata de um convite à admiração do universo em cada uma de suas partes, numa espécie de visão panteísta em que as divindades se apresentam sob a forma de répteis ou insetos. Não tanto a realidade como o seu conhecimento é aqui o problema aristotélico. Por que homens habituados ao conhecimento das realidades divinas deveriam dedicar a própria atenção aos seres desprovidos de logos? Fica claro que tanto no plano das coisas mais elevadas, quanto no plano do que é desagradável, a theoría, o conhecimento, não pode se justificar por meio do interesse ou utilidade - o controle, a dominação de pessoas, animais ou objetos. Se, quando observamos as imagens de animais cuja visão é desagradável, sentimos prazer, é porque consideramos neste momento (syntheoroûmen) a arte da criação, do artesão, como a pintura ou a escultura. Seria então paradoxal se não sentíssemos um prazer ainda maior na observação (theoría) da natureza destes animais, podendo nos dedicar ao estudo das causas.

O incômodo pela visão direta não se limita, porém, somente aos seres desprovidos de razão. Pois se alguém julga desprezível a observação dos animais, deveria desprezar igualmente a observação de si mesmo. Aristóteles argumenta que também as partes de nosso corpo - sangue, carne, ossos, veias - não são contempladas com prazer. Mas é preciso considerar que o fim não é a parte, mas o todo. Em outras palavras, o fim será a natureza, no que diz respeito ao estudo dos animais inferiores, ou o corpo humano, quanto à observação de cada parte anatômica. Anatomia humana, corpos mortos, animais desprezíveis: retoma-se, no tratado de história natural, os exemplos das imagens na Poética. Animais e cadáveres são, ao mesmo tempo, referência da composição artística e do conhecimento natural ${ }^{15}$.

$\mathrm{Na}$ Poética, a visão direta e dolorosa da natureza era oposta à sua representação agradável. Agora, no tratado sobre as partes dos animais, ao prazer, evidente, desta imagem se sobrepõe o prazer ainda maior, mas menos evidente, do conhecimento do que é representado. Como na Poética, estabelece-se assim um contraste

15 Aristóteles, Partes dos animais, I, 5, 645a5 s. 
entre a arte imitativa - que produz um conhecimento limitado, mas, ao que parece, também um prazer limitado - e o conhecimento sem limites do filósofo, ou, mais precisamente, do investigador da natureza.

Se o prazer da ciência, para ser demonstrado, chama em seu auxílio o prazer das imagens, o conhecimento poético, para se afirmar, se apóia no exemplo do filósofo. Com a mímesis os homens aprendem, diz a Poética; e a mímesis é agradável porque aprender é agradável para todos, "e não somente para os filósofos". No primeiro caso, realizando a mímesis, ou seja, imitando, os homens adquirem os primeiros conhecimentos. No segundo caso, aprender em geral (que provém da prática das imitações e de sua observação) é agradável. Também observar, e não somente imitar, é fonte de aprendizagem, porque - acrescenta Aristóteles - implica raciocinar sobre o que é cada coisa, saber que "este é aquele". Se a pintura torna claro qual é a natureza da mímesis artística, o conhecimento e o prazer em sua observação se exprimem através da arte do "retrato". Também esta pode ser uma ocasião para lembrar os primeiros tempos da arte: segundo um procedimento rudimentar, os primeiros pintores acrescentavam, junto às figuras representadas, os nomes que permitiam o seu reconhecimento ${ }^{16}$.

Os homens aprendem quando praticam a mímesis e quando observam as obras miméticas. Da prática da imitação se formam os poetas. Da observação dos objetos imitados, podemos sugerir, vão se formar os críticos, ou os autores de "poéticas”. O que faz Aristóteles senão aprender pela observação das obras e pela observação dos observadores? Da observação (theoría) em geral, do que existe por natureza e de seus produtos, e das imitações, vão se formar os filósofos. Mas o conhecimento dos filósofos implica uma continuidade que não pertence aos demais. Por conseguinte, de forma implícita mas clara, os poetas não serão nunca verdadeiros sábios.

5. Em que consiste este "aprender" que deriva da observação das imitações? Aparentemente, trata-se de identificar a representação no objeto que é representado. Em outras palavras, um verdadeiro reconhecimento. Este reconhecimento,

16 A relação de conhecimento que é aqui indicada, "este é aquele" (hoûtos ekeînos) (Poética, 4, 1448b17), é expressa na forma neutra, "isto é aquilo" (toûto ekê̂no), em Retórica, I, 1371b9. Também o reconhecimento na Poética - ver abaixo - diz respeito, em princípio, a pessoas, mas pode se referir a "coisas inanimadas": Poética, 11, 1452a34-35. Para os antigos pintores que escrevem, ver Tópicos, VI, 140a20, que se deve considerar conjuntamente com Eliano, Varia Historia, X, 10. 
dito em grego anagnórisis, é descrito como modo de conhecimento por Platão no diálogo Teeteto.

Como pode Sócrates saber que o indivíduo que está diante de si é seu amigo Teodoro? Sócrates reconhece Teodoro porque constata uma correspondência entre o indivíduo que vê e a imagem como fixada em sua mente, como uma impressão em um bloco de cera. Quanto mais precisa é a impressão na cera, tão mais seguro é o reconhecimento. Platão vai notar que esta explicação não dá conta dos vários processos de conhecimento (como poderíamos então conhecer os números?), mas, de fato, não a recusa no que diz respeito ao reconhecimento através de imagens sensíveis. Lembrando estas "marcas" na cera, mas transformando-as em verdadeiras pinturas, Aristóteles procura explicar o processo de imaginação, ou phantasía, ou seja, a representação em nossa mente de imagens sensíveis.

A imaginação é uma representação a que nos relacionamos com a mesma consciência que possuímos diante de uma pintura, ou seja, com a consciência da diferença entre imagem e objeto. Por um lado, temos o caráter imediato da percepção sensível: eu vejo alguém. Por outro lado, os processos da memória, em que vemos alguém que não está presente. O que não está presente nos é "apresentado" em uma imagem, mas não vemos, ou lembramos, a imagem que está em nossa mente enquanto objeto em si (diríamos, como uma obra em uma galeria), mas como o objeto que esta representa: "o animal pintado em um quadro é tanto um animal quanto uma cópia, ambos são um e o mesmo, mas o ser não é o mesmo para ambos". Em outras palavras, se uma imagem qualquer se apresenta na alma, na medida em que se relaciona a outra coisa, a alma a considera como uma cópia em uma pintura. É a própria alma a apresentar estes pensamentos e imagens "que se relacionam a outra coisa" em sua natureza, por assim dizer, "pictórica" ${ }^{17}$.

Esta distância entre imagem e objeto, que a nossa alma constata nas representações da phantasia, não existe no campo da opinião (dóxa), como diz Aristóteles em seu tratado sobre a alma: "quando acreditamos (temos opinião) que algo é terrivel ou assustador, imediatamente o sentimos, e o sentiríamos do mesmo modo se fosse tranqüilizante. Quanto à imaginação, seria como se observássemos em uma pintura coisas terríveis ou tranqüilizantes". Não sentimos, portanto, o mesmo medo diante do que "acreditamos" assustador e diante do que "imaginamos" assustador, porque sabemos que se trata, neste caso, de uma representação, e estamos

17 Platão, Teeteto, 192d s.; Aristóteles, De memoria, $450 \mathrm{~b} 20$ s. É preciso lembrar que o termo zóon indica não somente o animal, mas também a pintura, o que pode dar origem a uma tradução diferente do passo aristotélico: cf. Sorabji (2004), ad loc. 
conscientes da distinção entre a representação e seu objeto. $\mathrm{O}$ homem pintado e o homem real são tais - ou seja, homens - somente por homonímia, diz Aristóteles mais do que uma vez ${ }^{18}$.

Os objetos que causam temor são sentidos como "verdadeiros" por nossa alma se estão em nossas opiniões, mas como "cópias" se estão em nossa imaginação. As emoções de terror e medo nos lembram a situação trágica e sugerem a pergunta se, diante de Édipo, sentimos as emoções que são próprias à nossa imaginação. Mais uma vez, porém, Aristóteles, em vez de mencionar a cena trágica, retoma o mundo das imagens. Se as situações não são semelhantes é porque reagimos de forma diferente diante do terror e do medo "verdadeiros" e do terror e do medo "representados" em uma pintura. Poderíamos perguntar: a diferença entre as duas situações é de intensidade - o terror e o medo são mais fortes quando sentidos como reais do que quando sentidos como imitados? Ou de natureza - terror e medo são sentidos, em um caso, como verdadeiros e, no outro, como não verdadeiros? O terror quando escutamos Édipo é "real", no momento em que o sentimos, ou é como diante de um quadro? E ainda, ao contrário: pinturas e obras miméticas como a poesia - seriam tais como os objetos de nossa imaginação?

Seria possível responder que, no caso da narração trágica, tremor e piedade parecem "verdadeiros", transformando-se depois em prazer. Já as pinturas não fariam chorar ou tremer, pois entendemos desde o início a distinção entre representação e realidade. Mas não podemos nos acontentar com esta resposta, que desvaloriza a arte da pintura diante da narração trágica. Também os quadros podem ser, em nós, causa de alegria (e talvez de dor), como os objetos representados.

Com efeito, Aristóteles procura indicar, em outros momentos, a proximidade entre representação e realidade. $\mathrm{O}$ sentimento de dor e alegria que sentimos diante da semelhança é afim ao modo em que nos colocamos diante da verdade. "Se alguém, observando uma imagem, sente prazer somente por sua forma, é necessário que para ele seja agradável também a observação daquilo de que observa a imagem" ${ }^{19}$. A sensação de prazer diante de uma representação corresponde à sensação de prazer diante do objeto representado. Visto que o exemplo diz respeito a uma imagem agradável, não sabemos se aqui, como na tragédia, há uma inversão, no momento em que a imagem provoca dor. Não sabemos se, apesar da dor que poderíamos sentir diante de um quadro que representa coisas dolorosas (ou todos

\footnotetext{
18 Aristóteles, De anima, 3, 3, 427b20-24. Homonímia: por exemplo, Categorias, 1a3.

19 Aristóteles, Política, VIII, 1340a22 s.
} 
os bons quadros seriam agradáveis, conforme os exemplos da Poética?), sentiríamos prazer em sua observação, ou seja, prazer por esta dor: como no caso da dor que provoca em nós a tomada de consciência por parte de Édipo.

6. O "reconhecimento" faz parte, portanto, de nossos processos de conhecimento, assim como de nossa relação com as obras miméticas. Os exemplos aristotélicos para as imagens de nossa mente, com a comparação com a pintura, estão em relação direta com o processo de reconhecimento como ilustrado no Teeteto de Platão. Mas este termo, "reconhecimento", anagnórisis, é utilizado, na Poética, para indicar um elemento interno à trama poética. Não diz respeito ao conhecimento que o poeta adquire na imitação, e sequer ao "este é aquele" que caracteriza o prazer da observação das imagens.

O reconhecimento poético é relativo ao personagem da obra, e, em sua forma superior, tem por objeto indivíduos aos quais o personagem é ligado por amizade ou parentesco ${ }^{20}$. O herói trágico reconhece os "outros", através dos quais "reconhece" si mesmo. Este reconhecimento é uma propriedade da narração poética, mas não da relação entre o ouvinte e a obra: o ouvinte conhece já o que o personagem deve ainda "reconhecer". No exemplo das imagens, onde o termo anagnórisis não é utilizado, o observador "reconhece" na imagem o que já viu, e sente prazer. No caso da tragédia, é através do reconhecimento do personagem que o ouvinte sente as emoções de temor e piedade. Aproximamo-nos assim do tema, artístico e filosófico, da relação entre mímesis e conhecimento de si mesmo.

A dor que sentimos ao ouvir o herói trágico deriva do conhecimento que este adquire durante a ação. Mas o nosso prazer pela obra poética, segundo o exemplo das imagens, diz respeito ao processo de conhecimento que a imitação realiza. Um conhecimento que é indicado conforme o modo particular da relação de reconhecimento: "este é aquele". Se o reconhecimento "poético" está na origem da dor do herói trágico, o reconhecimento "mimético" está na origem do prazer, na audição da obra. O ouvinte, ou leitor, sente a dor e a alegria correspondentes a estes "reconhecimentos".

20 Para o reconhecimento "poético" ver Aristóteles, Poética, 11, 1452a30 s. (a passagem é da ignorância ao conhecimento e também da amizade à inimizade, mas é o primeiro aspecto que prevalece; no capítulo 16 encontra-se uma lista de reconhecimentos). Em Platão, o reconhecimento (anagnorízein) dos parentes (como na anagnórisis da Poética) deve ocorrer também através das palavras: Político, 258 a. 
Poderíamos, portanto, concluir que é através das obras imitativas que se tornam claros os nossos processos de conhecimento. E que, ao contrário, estes processos parecem mediar nossa percepção "estética", tanto no que diz respeito à imaginação, quanto no que diz respeito às obras miméticas.

Tal constatação, porém, não é suficiente para dar conta da amplidão da imagem pictórica na expressão de nossas relações com o mundo e com nós mesmos. $\mathrm{O}$ ato de pintar é lembrado quando se trata de campos ainda mais vastos do que o da imaginação. É a própria natureza, diz Aristóteles em um de seus tratados de história natural, que segue, na criação de suas obras, os procedimentos do pintor, inicialmente desenhando os contornos dos objetos - no caso, os animais -, em seguida dando-lhes detalhe e $\operatorname{cor}^{21}$. Se a arte imita a natureza, e não os pintores, a natureza imita os pintores, e não a arte.

Mas também na sua, e na nossa intimidade, a natureza não pode descuidar de seu modelo artístico e humano. Já o percebia Platão, no Filebo, quando, para preencher a tabuazinha da alma, alistava não somente o escrivão, mas também o pintor $^{22}$. Parece sugeri-lo Aristóteles, no tratado De Anima, quando observa a alma em sua atividade mais bela, se assim pudermos caracterizar a dupla natureza de nosso intelecto: por um lado, intelecto produtivo, ato distinto, impassível e puro; por outro, intelecto passivo, a se transformar em todas as coisas enquanto conhecimento. Ao analisar este estranho e difícil dobrar-se sobre si mesmo do intelecto - que é humano e, talvez, divino -, entre conhecer e ser conhecido, e ser passível de conhecimento, Aristóteles recorre novamente à tabuazinha e ao escrivão, assim como ao artista e à sua matéria: ou seja, ao pintor e sua obra. "Como faz a arte com sua matéria...": em meio a luz e cores, delineia-se em nós a nossa interioridade mais própria. Este artista de nossa alma, o intelecto, é artista de si mesmo, autor e objeto, compondo o mesmo intelecto, em potência e em ação, passivo e ativo segundo uma divisão que, talvez, espelhe somente os dois lados da mesma figura, como um pintor que fosse o seu auto-retrato ${ }^{23}$.

7. A natureza e o que em nós é mais íntimo imitam o artista. A imitação parece impor-se em todos os lugares e sobrepor-se à obra original. No entanto,

21 Aristóteles, Geração dos animais, II, 743b.

22 Platão, Filebo, 38 c s.

23 Aristóteles, De anima, III, 5, 430a s. (430a12: hô̂on he téchne pròs tèn hylen péponthen; em 430a16-17, a referência às cores). 
logo no tratado em que mais se dedica a estudar o agir imitativo entre os homens, Aristóteles nos faz ver os limites desta ação expansiva e penetrante. Se os primeiros conhecimentos derivam das imitações, não fica claro se os homens imitam para conhecer. Já o prazer que deriva da observação das obras poderia não depender somente dos conhecimentos adquiridos através da mímesis. Na Poética, sempre no quarto capítulo, Aristóteles acena à possibilidade de um prazer não mimético na pintura, e, talvez, na poesia: ou seja, um prazer que não justifica o conhecimento e que não se justifica enquanto conhecimento.

Sem ter visto os objetos representados - na ausência de representação não pode ocorrer o reconhecimento, não é possível constatar que "este é aquele". Todavia, o prazer da observação não é assim, necessariamente, anulado: não mais derivando do objeto identificado, não mais provindo do ato de identificação, este emanará das cores, das formas, da qualidade da obra. Um prazer que sentimos pelos elementos da pintura a que não nos relacionamos enquanto "conhecimento" ${ }^{24}$.

Com esta referência ao não mimético, Aristóteles pode abandonar o campo pictórico e voltar à consideração da poesia, indicando o que, na poesia, existe "por natureza". Como vimos, trata-se, para alguns, da segunda causa que Aristóteles atribui à origem do ato poético. Nesta, outros elementos "naturais" aparecem ao lado da mímesis, e, poderíamos deduzir, não são miméticos, a saber: a harmonia e o ritmo, do qual faz parte a métrica.

Na pintura, temos um elemento de conhecimento, a mímesis, e outros elementos que não necessariamente implicam conhecimento, ou reconhecimento, como as cores. Na poesia, teríamos igualmente o conhecimento, trazido pela mímesis, mas também a harmonia e o ritmo, e, portanto, a métrica. Harmonia e ritmo, formas e cores parecem permitir que as obras se libertem de seu destino imitativo. Já Platão falara da harmonia como a "cor" do $\log _{0}{ }^{25}$. Lembremos que, no início da Poética, Aristóteles opõe a visão comum que os homens possuem da poesia - é poesia o que se exprime em linguagem métrica - e a verdadeira natureza da poesia: é poesia o que realiza a mímesis. Seguindo a apresentação aristotélica da origem da poesia, encontramos os elementos aparentemente não miméticos - diríamos, propriamente "musicais", harmonia e ritmo - adicionados à mímesis poética, e não sabemos em qual medida o prazer que sentimos pela obra resulta de cada um destes elementos.

24 Poética, IV, 1448b17 s.: "E no caso em que não se tenha visto antes (o objeto da imagem que provoca prazer), não dará prazer enquanto objeto imitado (mímema), mas pela sua realização, pela sua cor ou por um outro motivo deste tipo".

25 Platão, República, X, 601 a-b. 
Para reiterar, porém, que a Poética de Aristóteles levanta problemas para os quais as respostas - aristotélicas, mas também as nossas - não são completamente claras, acrescentemos que tampouco podemos aceitar, com facilidade, esta divisão: mímesis poética, por um lado, harmonia e ritmo (e métrica), aspectos "musicais" e formais, por outro. Com efeito, sem formas e cores não haveria mímesis pictórica, e em vão lembraríamos o discurso desprovido de seu ornamento, de suas vestes - o discurso "nu" da prosa, incluída a prosa filosófica - para indicar o que é próprio à poesia, ou seja, a imitação.

Por outro lado, é o "ornamento" mesmo do logos, a sua "cor" que pode assumir a prerrogativa do prazer e do conhecimento de que parecia afastado. Retomando, na Política, uma longa tradição grega, também Aristóteles não esquece que a música é mímesis. A imitação do que se esconde no ser humano - a "morada" da alma, o êthos - ocorre musicalmente. Se é a pintura que nos revela os processos de imaginação e intelecção, é por meio da música que se obtém não somente a formação moral dos indivíduos, mas o conhecimento de nós mesmos, segundo a nossa particularidade. Enquanto tal, a música, exprimindo, na forma mais direta, não os efeitos passageiros ou as paixões, mas os estados em que se põe a alma segundo hábito, o seu caráter, é mais mimética do que a própria pintura ${ }^{26}$.

Fica o paradoxo: seriam não miméticos os elementos musicais que são em nós por natureza e que, segundo a Poética, se "acrescentam" à mímesis: harmonia, ritmo e métrica? E, neste caso, se podem provocar prazer, seriam secundários em relação ao conhecimento da mímesis ? Ou harmonia, ritmo e métrica realizam a mímesis da alma, sendo mais miméticos do que a arte da pintura, que ilustra a mímesis e os nossos processos de conhecimento?

Por um lado a arte, que revela o "conhecimento" nas imagens ou na ação, ou que reflete e ao mesmo tempo modela a alma; por outro, a filosofia, que observa não somente o mundo, mas também a arte segundo suas causas, segundo o seu fim, e não pode negar à arte a íntima convivência, prazerosa ou dolorosa, com o que ela mesma, filosofia, deseja conhecer ${ }^{27}$.

26 A relação entre música e êthos é desenvolvida por Platão na análise da educação musical no terceiro livro da República (398 c s.), com referência ao teórico da música Dâmon (400 c) e à importância da música para o conhecimento da alma (401 a-e). Para Aristóteles, ver Política, VIII, 1340a18 s. (com referência, neste livro, à Poética).

27 Para ulteriores discussões sobre estes temas e referências bibliográficas, ver Gudeman, 1934; Else, 1957; Lanza, 1987. Em particular, para uma análise da mímesis aristotélica na 
REFERÊNCIAS BIBLIOGRÁFICAS

Gudeman, A. Aristoteles, Peri Poietikes. Berlin-Leipzig: De Gruyter, 1934.

ELSE, G. Aristotle's Poetics: the Argument. Cambridge (Mass): Harvard University Press, 1957.

LanzA, D. Introduzione e note ad Aristotele, Poetica. Rizzoli, Milano 1987.

Halliwell, S. The Aesthetics of Mimesis . Princeton University Press, 2002.

SorabJI, R. (2004). Aristotle on Memory (1 ${ }^{\text {st }}$ Edition 2004). Chicago: University of Chicago Press, 2006.

Veloso, C.W. Aristóteles Mimético. São Paulo: Discurso Editorial, 2004.

Vernant, J. P. Nascita di immagini (1975), em Nascita di immagini e altri scritti su religione, storia, ragione. Milano: Il Saggiatore, 1982.

\begin{abstract}
King Oedipus can introduce us in a central theme discussed by Aristotle in the Poetics and in other works: the relationship between art and knowledge. This paper aims to investigate some topics connected to this theme, considering particularly the discussion on the causes of poetry in the fourth chapter of Poetics, and the function of images in the process of knowledge and imagination. The relationship between mimesis and the inner of the soul appears in Aristotle's analysis of intellect, and, as for the arts, in the field of music.
\end{abstract}

Keywords: Aristotle, techne, episteme, poetics, image, tragedy.

Poética e nas demais obras do filósofo ver Halliwell, 2002, cap. 6, e o estudo de Veloso, 2004. Para Platão, exemplar a análise de Vernant, 1975. 